\title{
Feature
}

\section{Meeting Report: The 2004 National Academies Summer Institute on Undergraduate Education in Biology}

William B. Wood ${ }^{* \dagger}$ and Jo Handelsman ${ }^{\ddagger}$

\author{
*Department of MCD Biology, University of Colorado, Boulder, CO; ${ }^{\ddagger}$ Department of Plant Pathology, \\ University of Wisconsin, Madison, WI
}

In 2002, a National Research Council (NRC) Committee was established to organize a series of National Academies Summer Institutes on Undergraduate Education in Biology (NASIUEB). The goal of these Institutes is to help undergraduate faculty in the life sciences, particularly those teaching large classes at research universities, apply findings from recent research about learning to improve their teaching in ways that will enhance student understanding and retention of biological concepts. The first of these Institutes took place at the University of Wisconsin in Madison (UW-Madison) during August 2003. It was a "pilot conference," including primarily biologists already involved in educational reforms and intended to provide proof-ofconcept for an intensive teaching workshop as well as ideas on how best to implement one. As reported in Cell Biology Education a year ago (Wood and Gentile, 2003), this meeting was judged a great success by the participants, and planning was begun for a second workshop aimed at the target faculty described above.

The second Summer Institute was also held at UWMadison, August 16-20, 2004, with major funding from the Howard Hughes Medical Institute (HHMI) in addition to support from the National Academies and the host university. As codirectors of this Institute, we worked with an active Steering Committee and local organizers to plan and implement the meeting. ${ }^{1}$ Instructors for the Institute were biologist-educators drawn from a variety of institutions; several had been participants in the 2003 pilot workshop. A complete list of the instructors and facilitators

DOI: 10.1187/cbe.04-07-0057

${ }^{\dagger}$ Corresponding author. E-mail address: wood@colorado.edu.

\footnotetext{
${ }^{1}$ Additional members of the Steering Committee are J. Gentile, Hope College (co-chair with W.B.W. of the NRC Committee on NASIUEB); I. Khan, Clark Atlanta University, and A. Chang, American Society for Microbiology. Others who assisted with planning and implementation were S. Lauffer, C. Pfund, S. Gossens, C.M. Pribbenow, M. Susman, and L. Tong from UWMadison, as well as A. Fagen, J. Labov, and K. Brenner from the NRC. Also present at the meeting as observers were Jennifer Donovan, HHMI; Shawn Drew and Adolphus Toliver, the National Institutes of Health (NIH); and Muriel Poston, from the National Science Foundation (NSF).
}

who participated can be found on the Institute's Web site at http://AcademiesSummerInstitute.org/.

The three dominant themes of the meeting were 1) active learning-ways to promote interactive student engagement during class in place of standard lectures; 2) assessmentways to make the monitoring of student understanding a continual, integral part of the teaching process; and 3) diversity - ways to design instruction that is effective for populations of students with diverse backgrounds, learning styles, goals, genders, and ethnicities. Participants were urged to adopt the standard of "scientific teaching" (Handelsman et al., 2004)-making changes, assessing their effects on student learning, and then further modifying teaching strategy based on the assessment results.

Admission to the Institute was by competitive application and was offered preferentially to those involved in teaching large introductory biology courses at research universities. Potential participants applied as teams of two or three from the same institution, with each team including one or two junior faculty members and one senior faculty member or administrator. A required component of the application was a commitment from the team's institution to cover travel expenses and to support team members in implementing teaching innovations following their return home. In addition, applicants pledged to collaborate at the Institute in the development of a "teachable unit" (TU), involving up to a week of class and laboratory activities, and after returning home, to implement at least one of the TUs developed at the Institute as well as a mentoring seminar for supervisors of undergraduate researchers (described further below). From a total of 37 completed team applications, 19 teams were chosen to participate in the Institute. The Steering Committee selected these applications on the basis of congruence between stated team goals and the Institute's goals of improving large introductory classes, quality of applicants' statements of purpose as judged by the Steering Committee, extent of institutional commitment, and, to a lesser extent, geographic and institutional diversity.

The meeting was at least as exciting as the pilot Institute in 2003, but in different ways, because many of the 2004 participants were new to the ideas presented. As an enticement for junior participants, opportunities had been arranged with appropriate UW-Madison departments for them to present seminars on their scientific research prior to 

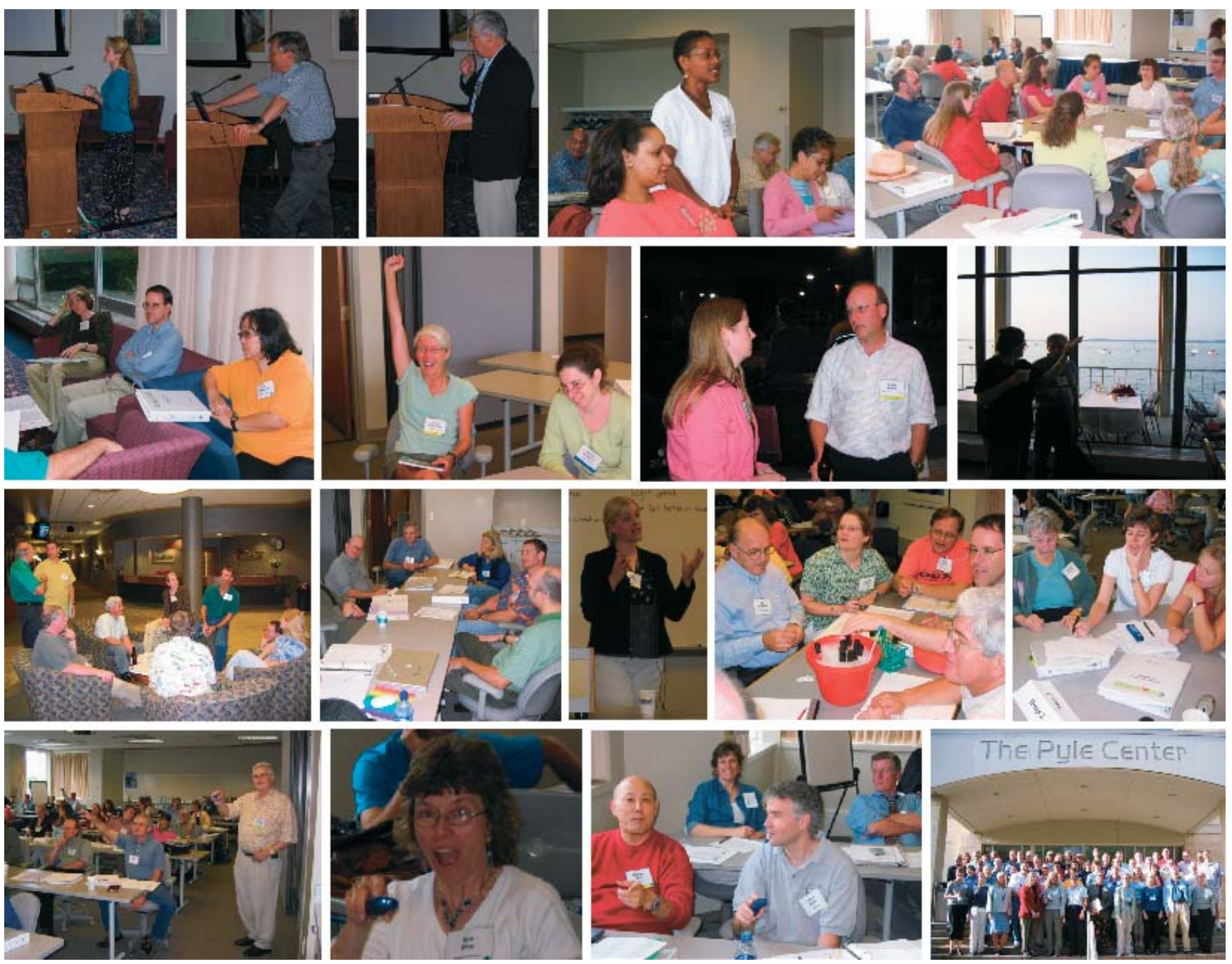

Figure 1. Top row (left to right): Jo Handelsman, principal organizer; Bill Wood, co-organizer; Bruce Alberts, keynote speaker; Shawn Drew, Ophelia Weeks (standing), Adolphus Toliver, Bruce Alberts, and Muriel Poston (in rear); Keith Garbutt, Gordon Uno, Catherine Merovich, Muriel Poston, Sue Wick, Joe von Fischer, Diane Ebert-May (from back), Kerry Brenner (from back), Robin Wright (from back); second row: Peggy Brickman, Norris Armstrong, Joan Miyazaki; Diane Ebert-May, Kerry Brenner; Robin Wright, Randy Phillis; view over Lake Mendota; third row: Bill Barstow and Michael Dini (standing), Phil Cunningham, David Njus, Peggy Brickman, Bill Wischusen, Norris Armstrong, Michelle Withers, Mike Hanna (from back); Randy Phillis, Doug Kline, Diane O'Dowd, Michael Dini, Jorge Busciglio; Sarah Lauffer; Bill Barstow, Michelle Withers, Mike Hanna, Norris Armstrong, David Njus doing the ice nucleation lab; creating a concept map: Victoria Finnerty, Rachelle Spell, Jenny Knight; fourth row: using "clickers" for active learning; Sue Wick actively learning with a "clicker;" Gordon Uno, David Wells (in front), Rachelle Spell, Marty Tracey (in rear); participants in the 2004 Summer Institute.

the meeting proper. The first evening featured an inspirational keynote address by National Academies President Bruce Alberts, after which participants began four intensive days of presentations and group work on TUs. During the group sessions, a trained facilitator worked with teams of six to eight participants on TUs in six different biological areas, representing interests of the group members as well as topics covered in a typical introductory course. In addition to the formal activities on the schedule, participants were urged to join one of several informal roundtables each morning at breakfast to discuss topics of common interest identified in the participants' applications, including how to balance teaching and research, challenges of teaching biology courses to nonmajors, how to encourage skeptical colleagues and teaching assistants to adopt better teaching practices, ways to increase student participation in large lectures, and use of information technology in the classroom. A daily newsletter appeared each morning previewing the day's events, highlighting activities of the previous day, and providing additional information and resources.

The three themes of the conference were modeled in the presentations, most of which included active engagement of participants and some assessment of their understanding. Among the highlights were interactive presentations by Diane Ebert-May (Michigan State University) on assessment, Sarah Lauffer (UW-Madison) on inquiry-based laboratories, 
and Robin Wright (University of Minnesota) on active learning strategies. Jo Handelsman and her colleagues introduced materials for an 8-week mentoring seminar they have developed at UW-Madison for graduate students and postdocs who supervise undergraduates in laboratory research; the summer participants are expected to implement this seminar in their home departments during the coming year. The week was capped off with presentation-demonstrations by each of the six groups on the TUs they had developed over the preceding four days. Presentations were reviewed and commented on by a panel of UW-Madison educators, who offered valuable feedback to the presenters. To their credit, all six groups produced essentially complete TUs suitable for participants to take home and implement in their 2004-2005 teaching.

The Institute was intense, without much time for socializing, reflecting, or even sleeping, but it appeared to be exhilarating for the participants, many of whom had never attended a teaching workshop previously. The atmosphere of excitement that pervaded the conference is best conveyed by the written comments of participants on a feedback questionnaire at the end of the week, some of which are reproduced below.

This institute produced usable products that I can adapt \& implement immediately. We got feedback-could also compare our approach to others; the process also modeled how I could create similar units on my own. Incredibly useful!

This has been an excellent experience that far exceeds any other educational workshops that I've attended. We actually created something useful!

There is no comparison - this institute has been several orders of magnitude more useful than every other workshop I have attended in the last 6 years.

Analogous to the summer courses at MBL in Woods Hole-total immersion, intense focus, quick pace. Very intense, demanding, information-rich. Should have long-lasting effects on my teaching.

One of the most intense but rewarding (and educational) experiences in my professional career! Thanks for the opportunity.

I haven't felt the same excitement since I went to my first research conference.

This will change my approach to teaching and my professional career!

Participants who completed the 2004 Summer Institute have been designated National Academies Education Fellows in the Life Sciences for the 2004-2005 academic year. In addition to this recognition, Fellows will each receive a stipend of $\$ 1,500$ to help implement their planned teaching changes and to promote the spread of ideas from the Institute to their departmental colleagues. Institutions are expected to match the Fellowship stipends. HHMI will host a follow-up meeting in January 2005, at which a representative from each institutional team will report on progress in implementing their TUs and mentoring seminar, teaching and learning opportunities they have experienced, and problems they have faced. In the meantime, participants are urged to stay in touch through the Institute's Web site.

Although the Summer Institute can accommodate only about 40 participants, we anticipate that it will create a ripple effect with far-reaching consequences. Participants in the 2004 Institute will teach an estimated 22,000 students during the coming academic year and will supervise more than 100 teaching assistants. Undergraduate science courses at large research universities must be improved if we are to provide the majority of our students with the conceptual understanding of science in general, and life sciences in particular, that they will need to be effective citizens in the twenty-first century, whether or not they become practicing biologists (National Research Council, 2003). We expect that graduates of the Summer Institutes, many of whom are or will become respected researchers in their fields, will spread what they have learned about teaching to colleagues at their home institutions and their professional societies who are still unaware of the exciting improvements in undergraduate teaching that are gaining momentum nationwide. Funding is being sought for a research effort that will evaluate the impact of the Institute on the teaching practices of its graduates, on their departments, and on their students. Planning is under way for similar Summer Institutes in other science disciplines. The NASIUEB will be continued annually, possibly offering two summer sessions each year if resources permit. Those interested in future participation should consult the Institute's Web site for additional information and application procedures at http://AcademiesSummerInstitute.org/.

\section{ACKNOWLEDGMENTS}

We are grateful to Bruce Alberts of the National Academies and Peter Bruns of HHMI for their enthusiasm and support of the NASIUEB, from its early planning stages through the 2004 Summer Institute.

\section{REFERENCES}

Handelsman, J., Ebert-May, D., Beichner, R., Bruns, P., Chang, A., DeHaan, R., Gentile, J., Lauffer, S., Stewart, J., Tilghman, S.M., and Wood, W.B. (2004). Policy forum: Scientific teaching. Science 304, 521-522.

National Research Council. (2003). BIO2010: Transforming Undergraduate Education for Future Research Biologists. Washington, DC: National Academies Press.

Wood, W., and Gentile, J. (2003). Meeting report: the first National Academies Summer Institute for Undergraduate Education in Biology. Cell Biol. Educ. 2, 207-209. 